\title{
The New Territories
}

The irony of imperial nationalism was that it was through movement that the "sedentarist metaphysics" of the territorial nation-state took hold. ${ }^{1}$ The steamship and the railway carriage produced practices of seeing and self-knowing that encouraged imperial travelers and colonial boosters to observe colonized peoples as outside of the Japanese nation in space and behind the Japanese nation in time. But it was not enough to deny the coevalness of colonized peoples-imperial travelers and colonial boosters also had to affirm the place of the nation on colonized land. ${ }^{2}$ In this, their methods of locating colonized lands illuminate an aspect of the spatial politics of empire that studies of the representation of colonial difference in the context of Western empires and previous studies of travel in the Japanese Empire have overlooked. Colonial boosters and imperial travelers did mark colonized peoples as not-yet-civilized, as primitive, and as backward. Yet this, in and of itself, was not justification enough for colonialism in an era in which the project of empire was transitioning from one of territorial acquisition to one of territorial maintenance. Colonial boosters and imperial travelers also had to locate colonized land within the nation in space and in synchronicity with the nation in time.

In the decades following the Russo-Japanese War, colonial boosters turned to tourism to create a social imaginary of the nation that incorporated Korea, Manchuria, and Taiwan as places within the space of the nation. These colonial boosters were a loose confederation of colonial officials, industrialists in the colonies and metropole, and, increasingly, public-private booster organizations, such as the Japan Tourist Bureau, the Taiwan Association, the Korea-Manchuria Information Bureau, and the Manchuria-Mongolia Culture Association, who worked to shape the public image of these places for both Japanese and foreign audiences. The 
individuals in these organizations would not likely have recognized themselves as members of a larger group called "colonial boosters." Nor did they always agree-settlers, for example, were oftentimes critical of decisions by the governors general that limited the privileges of settlers vis-à-vis colonized subjects or their ability to capitalize on colonial resources to the fullest. ${ }^{3}$ But they did share a desire to make permanent Japan's colonial holdings and to get their compatriots to see these places (if not their peoples) as necessary components of the nation. In that, they shared much with the boosters who inaugurated imperial tourism to other colonial sites, such as New Zealand, the American West, and the Caribbean. ${ }^{4}$

In the face of growing anxiety over the future of Japanese colonial rule in Korea, Manchuria, and Taiwan, the colonial governments and the South Manchuria Railway Company intervened directly to shape how imperial travelers understood the place of the new territories within Japan. One strategy they adopted was mounting industrial exhibitions in colonial capitals to draw metropolitan travelers to the colonies, and sending elaborate pavilions to be displayed at exhibitions in the metropole. ${ }^{5}$ But metropolitan attendance at colonial exhibitions was generally low, and the complications of shipping flora, fauna, and historic artifacts limited what could be sent abroad for display. Rather than rely solely on short-term, big-ticket exhibitions, the colonial governments and the South Manchuria Railway Company turned to tourism and its central technologies, the itinerary and the tourist guidebook, to transform select portions of Taiwan, Korea, and Manchuria into permanent exhibitions. By carefully curating what travelers saw and how they made sense of these sights, the colonial governments and the South Manchuria Railway Company sought to teach imperial travelers to see Korea and Taiwan as places within the space of the Japanese nation, and Manchuria as a place that was, if not within the space of the Japanese nation, then at least outside of the space of the Chinese nation.

Colonial boosters encouraged imperial travelers to place colonized lands within Japan through two acts of transposition. One was the transposition of the landscape into a position within the space of civilization, in which relations within networks of circulation and exchange and a progressive historical time of development determined the essence and location of a place. ${ }^{6}$ The another was into the space of the nation, in which the location and essence of a place was primarily determined by its relation to an imagined end point of History, that is, of the nation's coming into being in its present-day territory. If, in earlier eras, it had been enough to declare conquered lands terra nullius, by the mid-nineteenth century, empires began to locate their conquered lands within what we might think of as the "mosaic" or "jigsaw puzzle" metageography of the international system of nation-states. ${ }^{7}$ The nineteenth century was, after all, an era that saw the particularization of civilizing missions in terms of national futures, such as Manifest Destiny in the United States or "Japanification" in Japan, as well as the incorporation of the 
United States and Japan into the European system of states with its idealization of the territorial nation-state. ${ }^{8}$ Intellectuals in Japan and the United States understood that the history of civilization was also a history of national becoming. ${ }^{9}$

Rather than simply denying the coevalness of colonized territory, colonial boosters used three modes-the historical, economic, and nationalist modes-to place Korea, Manchuria, and Taiwan within the bounds of a past, present, and future that was both "civilized" and "Japanese," and at the same time, to mark colonized subjects as "out of place" in these same lands. In this, colonial boosters enrolled imperial travelers in the project of constructing a spatial imaginary of the nation that might one day overcome the core-periphery geography of civilization to encompass the entirety of the territory of the state. Thus the boosters' project was, in fact, threefold. One, they sought to teach travelers to see the colonial landscape as already part of a global space of civilization, rather than as places that remained forever behind the inner territory in developmental time. Two, they sought to teach travelers to see the colonies in such a way that it would be possible, in the present and in the future, for metropolitan Japanese people to see the progressive force of Japanese history as being located in the "new territories" as much as it was in the "inner territory" And three, in the service of the first two goals, they applied the same discursive mechanisms that they used to place the Japanese nation on colonized land to dis-locate or dis-place colonized subjects from the colonized territory that they inhabited.

\section{THE WORLD OF JAPAN: AS SEEN FROM THE CORNER-OR PERHAPS THE CENTER}

By the time the Government General of Korea published its first tourist guidebook in 1915, the territory of the Japanese state had taken the form that it would hold until the establishment of a puppet state in Manchuria in 1932. After an initial period of colonization, which claimed Hokkaidō and Okinawa, the Japanese state acquired Taiwan in 1895. The settlement of the Russo-Japanese War netted the empire the southern portion of the island of Karafuto, the Railway Zone in southern Manchuria, and the Kwantung Leased Territory at the tip of the Liaodong Peninsula in 1905. In 1910, the Japanese state annexed Korea, making the peninsula a formal part of Japanese territory. Then, in 1914, the state claimed the German colony of Micronesia, a conquest that the League of Nations would later ratify by declaring Micronesia to be a Class "C" Mandate Territory under the guardianship of Japan.

Representations from the imperial center described the relationship between the territory of the state and the space of the nation as one of a progressive outward expansion, in which the space of the nation expanded along with the territory of the state. The 1919 textbook map we examined in the introduction is one 
example. But the representation of Japan as an expanding national-historical space stood in stark contrast to the actual structure of imperial rule, in which Korea and Taiwan were excluded from the jurisdiction of the Constitution. ${ }^{10}$ Likewise, this representation ignored the very real differences between the government of the main islands, Japan's formal colonies, and its informal possessions in the Kwantung Leased Territory and the Railway Zone in Manchuria.

Colonial discourse defined Korea, Manchuria, and Taiwan as uncivilized places, for it was this lack of civility that justified the treatment of the colonies as spaces of exception to national norms. Cadastral surveys, for example, were one mechanism by which the colonial governments incorporated colonized lands into the territory of the state while still marking them as outside of the space of the nation. Undertaken by the Government General of Taiwan from 1898 to 1903 and the Government General of Korea from 1910 to 1918, these surveys became a means by which the Governments General translated the discourse of colonial incivility into actual practices of dispossession. In Taiwan, the Government General delineated the mountainous interior region of the island as a special administrative zone because of its "savagery," and declared all the land within that zone to be public land. In the Government General's argument, indigenous peoples who resided in the area did not have a concept of private property and therefore could not have owned the land prior to the establishment of the Japanese colonial government. The Government General's own research later contradicted this assessment. Nevertheless, it became the basis for the large-scale transfer of legal ownership of land to the Japanese colonial government. ${ }^{11}$ In Korea, it was not the cadastral survey itself that led to the dispossession of Korean landowners but rather its subsequent effects. In its determination to make Korea an agricultural appendage of Japan, the Government General encouraged individual landowners to shift their production to rice, which would be sold to consumers in the industrializing metropole, and sweetened the deal by subsidizing improvements necessary to increase production. When the price of rice collapsed in the 1920s, however, so did the welfare of a majority of Korean farmers. In the aftermath, the Japanese-owned Oriental Development Company became the largest landowner in Korea. ${ }^{12}$

The colonial legal system likewise translated the discourse of colonial incivility into institutional exceptionalism. The Governments General operated under two laws, known as Law 63 in Taiwan and Law 30 in Korea, which granted the governors general the authority to issue ordinances that had the power of law-to bypass, in other words, the Imperial Diet and any local legislative bodies and to rule by decree instead. In the inner territory, such power was reserved for the emperor. Enabled by Laws 63 and 30 , the governors general enacted penal rules for the colonies, such as the use of flogging to punish colonized subjects, which were specifically disallowed by the inner territory's Civil Code. These practices were necessary, the colonial governments argued, because colonized subjects lacked 
a level of development that would enable them to respond to more "civilized" punishments. $^{13}$

Manchuria was a slightly different case. Yet even here the discourse of incivility enabled special practices that marked Manchuria as a place both within and without the space of civilization. For example, Japanese residents enjoyed the privilege of extraterritoriality in Manchuria. The practice originated in the so-called unequal treaties that Western powers signed with China and Japan, and later Japan with China, in the late nineteenth century. These treaties granted foreigners the right of extraterritoriality in China because, the argument went, local courts were uncivilized, and foreigners ought not to be subjected to their barbaric justice. In Manchuria, Japanese residents had the right to be tried in Japanese consular courts staffed by Japanese magistrates, who would determine their fate under the rules of Japanese, rather than Chinese, law. Moreover, extraterritoriality justified the creation of a Japanese consular police force, whose duty it was to protect the property rights of Japanese residents. ${ }^{14}$ From this stemmed the establishment of a Japanese court system whose rulings superseded those of the Chinese magistrates (at least the Japanese court argued as such) and would come to form the foundation of a large-scale transfer of Chinese land to Japanese ownership in the 1920 . $^{15}$

In each case, the Governments General and the South Manchuria Railway Company legitimated practices of dispossession through the legal and administrative constitution of Korea and Taiwan as somehow apart from the space of the nation, and Japanese Manchuria as apart from both China and the space of civilization. At the same time, the representation of these places and their peoples as somehow outside of the Japanese nation in space and behind the Japanese nation in time imparted to many Japanese residents of Korea, Manchuria, and Taiwan a sense of precarity. In the case of Manchuria, settlers worried that Japanese politicians and officials cared little about the future of the Railway Zone and the Kwantung Leased Territory. They were not wrong to worry-indeed, commentators in the metropole questioned the "worth of the whole enterprise." ${ }^{16}$ Despite early imperial travelers' insistence that Manchuria constituted an essential component of the national land, others argued that the permanent colonization of Manchuria was a dangerous and unnecessary endeavor. In the years immediately after the establishment of the South Manchuria Railway Company in 1906, powerful voices advocated pulling back, while others, such as Gotō Shinpei, demanded pushing forward toward direct colonization. Itō Hirobumi, a towering figure in Japanese politics, succinctly summed up the problem. "Japan's rights in Manchuria are nothing more than the leased territory . . . and the railway," Itō stated. "Today, officials and even businessmen speak readily of 'managing Manchuria.' But Manchuria is in no way part of Japan. It is no more and no less than one part of China's territory. We have no right to speak of exercising sovereignty in a territory that doesn't belong to us." ${ }^{17}$ Japanese expansionists continued to pursue territorial 
gains opportunistically throughout the 1910s and 1920s-most famously through the presentation of the "Twenty-One Demands" to the Chinese government in 1915, one of which resulted in the extension of Japan's leasehold in Manchuria to ninety-nine years. Yet others worried that the international embrace of the territorial nation-state as the foundation of world peace, combined with the rise of the Chinese nationalist movement, meant that further territorial expansion in Manchuria would be perceived as aggression against an extant state rather than expansion into the fictive white space of terra nullius. ${ }^{18}$ As it had been during the Russo-Japanese War, the question of whether Japanese expansion into Manchuria was in the best interests of the nation remained an active question.

Japanese settlers and colonial administrators in Korea likewise felt the tension of their not-quite-in / not-quite-out status. Japanese colonial discourse emphasized the long, shared history of Japan and Korea and argued that a Japanese "annexation" (heigō or gappei) of Korea would be a reunion between two civilizations with shared ancestry yet disparate histories. Yet travelers' representations of Korea in the early twentieth century gave short shrift to the common ancestry thesis and instead described the peninsula as a strange and dirty backwater. Okita Kinjō’s description of Korea in his 1905 Rimen no Kankoku (Korea behind the mask) is illustrative in this regard. Okita acquiesced to the geography of civilization's insistence on defining regions in terms of what they produced for exchange. But he described Korea's products as ones of questionable value to civilization's market: according to Okita, the "seven major products" of Korea were "shit, tobacco, lice, courtesans, tigers, pigs and flies."19 Such a discourse certainly buttressed Japanese claims for the legitimacy of the Government General's civilizing mission. ${ }^{20}$ Yet it also fostered the insecurity of Japanese settlers, who, by the early 1910s, were fighting to overcome the strictures that the idea of Korean backwardness placed on their own economic activities in the peninsula. ${ }^{21}$ Some commentators feared that life in Korea was Koreanizing, or "yobo-izing" Japanese settlers (yobo was a derogatory term that Japanese settlers applied to Koreans) instead of Japanifying Koreans. ${ }^{22}$

Further intensifying the spatial and territorial anxieties of Japanese setters in Korea were metropolitan attitudes toward the project of colonialism itself. In the lead-up to the opening of the 1915 Korean Products Competitive Exhibition in Keijo, the press and the Government General of Korea expressed concern that residents of the metropole were disengaged from the task of assimilating Koreaa practice that aimed to Japanify Koreans through language training and other external changes, such as customs and social organization. ${ }^{23}$ As one editorial in the Tokyo Asahi Newspaper put it, the major goals of colonial development depended on the ability of the Government General to invest the Japanese nation in the future of Korea. It was not enough for Japanese to stand by and watch colonization happen, the editorial argued. The project required participation. ${ }^{24}$ None was more conscious of this than the governor general himself, who could project no 
near-term future in which the colonial administration would not be operating at a deficit. ${ }^{25}$

In the case of Taiwan, the discourse of colonial savagery and weak metropolitan commitment likewise flustered Japanese settlers and the colonial government. In the 1895-96 military campaign to wrest control of Taiwan from Chinese guerrillas and indigenous peoples who opposed Japanese rule, the metropolitan media introduced Japanese readers to the "customs" of indigenous life-hunting, gathering, and headhunting - while likewise portraying Taiwanese Chinese as lawless bandits, whose ragged uniforms and lack of valor contrasted with the spotless white uniforms and bravery of the Japanese soldiers. ${ }^{26}$ By the turn of the century, however, the equation of Taiwan with savagery struck colonial boosters in both Taiwan and the inner territory as both old news and the key cause of the lack of metropolitan investment-both financial and emotional-in the future of the island. In the face of the steep expense of establishing a colonial government, there had been calls to sell back the island to China at any price. ${ }^{27}$ In response, boosters proposed ways of increasing metropolitan appreciation for Taiwan. In 1899, for example, Nakahashi Tokugorō, the president of the Osaka Mercantile Shipping Company, which enjoyed a government monopoly on regular services from the metropole to the island, suggested renaming the island Nan'yōdo (South Seas province), because people associated the name Taiwan with the savagery and death of Japan's past encounters with the island. "Therefore," he argued, "it's necessary to change it to a splendid and beautiful name that bears no relation to anything that came before." ${ }^{28}$ Likewise, members of the Taiwan Association (Taiwan kyōkai), a booster organization headquartered in Tokyo, attempted to elevate the civilizational status of Taiwanese Chinese in the metropolitan imagination by referring to them in a way that did not condemn the island as a whole to an image of savagery and lawlessness. The Taiwan Association argued that referring to Taiwanese Chinese as "Taiwan natives" (Taiwan dojin) conjured up comparisons to "Hokkaidō natives" (Hokkaidō dojin), in other words, the Ainu, and therefore, of an entire island that was "savage" in character. Instead, the boosters suggested "people of Taiwan" (Taiwanjin) or "islanders" (hontōjin), two terms that lacked any overt reference to a linear trajectory of civilization development or pejorative characterization of the island's essential nature. ${ }^{29}$

Tied in with these concerns was, for the largely Japanese population of boosters around the empire, the problem of how to refer to Japanese people themselves. As the Taiwan Association pointed out, though official and popular discourse oftentimes referred to Japanese people as "inner territory people" (naichijin), this moniker only made sense if one thought of Japanese identity from the perspective of a colonial periphery looking back on a metropolitan core. It naturalized a hierarchical division between inner territory and new territory that settlers hoped to eventually overcome, at least in terms of their own place within Japan. Instead, Taiwan 
boosters suggested "people of Japanese culture" (wajin), in contrast to "people of Chinese culture" (kanjin) - a division that incorporated all Japanese people, regardless of place of residence, into the same category and upset the spatialization of the inner territory as the center of the empire. ${ }^{30}$ In Manchuria, the leaders of Japanese civil society in Dairen likewise referred to themselves as "imperial national people" (teikoku kokumin) or "Japanese subjects" (Nihon shinmin), two terms that expanded the space of authentic Japanese nationality to include Manchuria. In Korea, settlers slipped between referring to themselves as "inner territory people" (naichijin) and as "Japanese people" (Nihonjin), a term that defined Japanese-ness in terms of parentage rather than location. ${ }^{31}$

\section{PLACING THE NEW TERRITORIES}

In the years between the first tours of Manchuria and Korea in 1906 and the creation of an imperial tourism industry in 1918, the number of metropolitan residents traveling to observe the new territories grew steadily. ${ }^{32}$ It was in this context of colonial anxiety and a growing market for imperial travel that the colonial governments and the South Manchuria Railway Company embraced tourism as a tool for re-placing the new territories in the metropolitan imagination. In 1908, the Government General of Taiwan published the first Japanese-language tourist guidebook to Taiwan, the unimaginatively titled Tetsudō ryokō annai (Guide to railway travel). The South Manchuria Railway Company followed in 1909 with its first Japanese-language guidebook, Minami Manshū tetsudō annai (Guide to railways in southern Manchuria). The Government General of Korea entered the field in 1915 with its own official guidebook, the Chōsen tetsudō ryokō annai (Guide to railway travel in Korea).

A few years later, the colonial Governments General and South Manchuria Railway Company were aided in their efforts to facilitate imperial travel by the Japan Tourist Bureau and the Korea-Manchuria Information Bureau. Eager to promote the growing trend of imperial travel further, in 1918 the empire's major transportation institutions joined with the Japan Tourist Bureau (JTB) to begin services for domestic travelers. The new services built on those that the Bureau of Railways, railway and steamship companies, and hotels had begun offering to foreign travelers through the JTB in 1912. At that time, the JTB opened offices not only in Yokohama and Kōbe, two major ports of entry for travelers coming across the Pacific Ocean, but also in Hōten, Dairen, Keijō, Pusan, and Taihoku, where the JTB offered tourist information and guide services. With the turn to the domestic market (which, in this case, also meant the imperial market), the JTB updated its physical footprint as well. In 1925, the organization added offices in locations that catered to the circuits and pathways of Japan's growing middle class-Osaka, Kyōto, and Tokyo's Nihonbashi Mitsukoshi department store. Other 
tourist organizations began services as well, such as the South Manchuria Railway Company's new Korea-Manchuria Information Bureau, which in 1923 set up offices in Tokyo's Marunouchi Building, Osaka's Sakai-suji Street, and in front of the station at Shimonoseki, the gateway to Korea. ${ }^{33}$

Concomitant with its turn to the domestic market, the Japan Tourist Bureau published its first compendium of tourist itineraries in 1920. The South Manchuria Railway Company's Korea-Manchuria Information Bureau followed soon after with its own set of itineraries in $1923 .{ }^{34}$ These itineraries guided travelers through their observations of colonized lands with little emphasis on encounters with colonized cultures or peoples. Instead, the itineraries directed travelers to sites that signified the success of the Governments General and the South Manchuria Railway Company at placing colonized lands within the space of civilization and the space of the nation: sites of production and circulation, sites that defined the past of each colonized land as a linear history of transition to Japanese rule, and sites that located colonized lands within the affective space of the national land and a collectively experienced national past.

Together, tourist guidebooks and itineraries did not present a "Japanese" view of the colonies in contrast to a colonized one. They presented a boosters' view of the nation, one directed at metropolitan Japanese who did not have the level of attachment to the new territories that colonial boosters' desired. In fact, the guidebooks differed markedly from another "Japanese" representation of the colonies. In 1913, the Japanese Bureau of Railway's published its first English-language guide to the empire, An Official Guide to Eastern Asia. Modeled after the Baedeker guides in Germany, the Official Guide sought, in the words of its primary sponsor, Gotō Shinpei, to "advertise Japanese culture and the Japanese spirit to the entire world." For Gotō, this meant moving from an understanding of Japan in the universal terms of civilization to one more particular to the Japanese nation. "In other words," he wrote, "to contribute to making rapid progress in moving from 'Japan in the World' to the 'World of Japan." 35 To introduce foreign travelers to the world of Japan, the Official Guide included pages and pages on Japanese, Manchurian, and Korean geography, history, and customs (Taiwan and Okinawa were contained in volume 2, Southwestern Japan). The guidebook represented East Asia from the perspective of the Japanese Empire, which was cast as the point of translation, both in terms of transport geography and knowledge, between East and West. ${ }^{36}$

The guidebooks published by the Governments General and the South Manchuria Railway Company for Japanese travelers likewise sought to translate the landscape into terms readily understandable by metropolitan travelers. But they were far more circumspect about the necessity of knowing anything about colonized subjects. "This book," the Government General of Korea wrote in the opening pages of the 1915 Chōsen tetsudo ryokō annai, "notes almost all of the famous places, historical ruins, and scenic sights along the lines of the Korean 
TABLE 1 A suggested itinerary for Korea-Manchuria travel. This two-week itinerary was the shortest itinerary for Korea-Manchuria travel. Longer itineraries took travelers farther afield in Manchuria, to the Russian-controlled cities of Harbin and Kirin in the north and to the port of Eikō on the Liao River.

\begin{tabular}{|c|c|c|}
\hline Day & Location & Sights to Be Seen \\
\hline 1 & Tokyo & [none] \\
\hline 2 & Kobe & [none] \\
\hline 3 & At Sea & [none] \\
\hline 4 & At Sea & [none $]$ \\
\hline 5 & Dairen & Wharf, soybean oil factory, city \\
\hline 6 & $\begin{array}{l}\text { Dairen-Port } \\
\text { Arthur-Dairen }\end{array}$ & $\begin{array}{l}\text { Hakugyokuzan Memorial Tower, museum, memorial exhibit } \\
\text { hall, various battlefields, old and new cities }\end{array}$ \\
\hline 7 & Dairen & $\begin{array}{l}\text { West Park, Electric Amusement Park, South Manchuria Railway } \\
\text { (SMR) Central Laboratory, SMR Sakakō (locomotive) factory, } \\
\text { SMR Ceramics Laboratory, Hoshigaura }\end{array}$ \\
\hline 8 & Hōten-Bujun-Hōten & $\begin{array}{l}\text { Open-air mine, Mondo tile factory, various mines, other } \\
\text { factories }\end{array}$ \\
\hline 9 & Hōten & $\begin{array}{l}\text { Inner castle [Chinese city], palace, Northern Tomb, new city, } \\
\text { West Tower, Golden Temple, Hōten Park, Shōkawanuma Pond, } \\
\text { Southern Manchuria Medical School }\end{array}$ \\
\hline 10 & Heijō & $\begin{array}{l}\text { Daidō Gate, Renkōtei Pavilion, Botandai Pavilion, Otsumitsudai } \\
\text { Pavilion, Genbu Gate, Fuhekirō Pavilion, Yōmeiji Temple }\end{array}$ \\
\hline 11 & Keijō & $\begin{array}{l}\text { Nanzan Park [Keijō Shrine], Government General building, } \\
\text { Museum, Keifuku Palace, Pagoda Park, Commercial Products } \\
\text { Exhibit Hall, Arts Manufactory }\end{array}$ \\
\hline 12 & Keijō-Pusan & [none] \\
\hline 13 & Shimonoseki-Tokyo & [none] \\
\hline 14 & Tokyo & [none] \\
\hline
\end{tabular}

SOURCE: Japan Tourist Bureau, ed., Ryotei to hiyō gaisan Taishō 12-nen (Tokyo: Japan Tourist Bureau, 1923), 256-58.

Railways." With its comprehensive guide to Korea's sights to be seen, the guidebook was "truly the best companion for those who wish to travel Korea." ${ }^{37}$ It was possible, in this formulation, to know Korea without learning a thing about contemporary Koreans, as the guidebook contained nothing related to Korean customs or culture in present use.

In fact, the first editions of official Japanese-language tourist guidebooks contained few textual descriptions of colonized subjects or colonial cultures. They did occasionally include a picture of colonized subjects, but only as part of a photo 
TABLE 2 A suggested itinerary for Taiwan travel.

\begin{tabular}{|c|c|c|}
\hline Day & Location & Sights to Be Seen \\
\hline 1 & Tokyo & [none] \\
\hline 2 & Kōbe & [none] \\
\hline 3 & Moji & [none] \\
\hline 4 & At sea & [none] \\
\hline 5 & At sea & [none] \\
\hline 6 & $\begin{array}{l}\text { Kiryū-Taihoku- } \\
\text { Maruyama }\end{array}$ & $\begin{array}{l}\text { Museum, Taihoku Park, Government General, Botanical } \\
\text { Garden, market; Taiwan Shrine, Kenzawa Temple, Maruyama } \\
\text { Park }\end{array}$ \\
\hline 7 & Taihoku-Taichū & $\begin{array}{l}\text { Taichū Shrine, Taichū Park, market, Teikoku Sugar Taichū } \\
\text { factory }\end{array}$ \\
\hline 8 & Taichū-Nichigetsutan & Sun-Moon Lake, Savage Tribe \\
\hline 9 & Nichigetsutan & [none] \\
\hline 10 & Kagi-Arisan & Mt. Ari Shrine, Sacred Tree \\
\hline 11 & Mt. Ari-Kagi & [none] \\
\hline 12 & Kagi-Hokkō-Tainan & $\begin{array}{l}\text { Timber factory, Kagi Shrine, Kagi Park, Hokkō Shrine, } \\
\text { Oriental Sugar Hokkō Factory }\end{array}$ \\
\hline 13 & Tainan-Takao & $\begin{array}{l}\text { Kaizan Shrine, Confucian Temple, Prince Kitashirakawa } \\
\text { memorial sites, market, Fort Provincia, salt fields, Anpin Port, } \\
\text { Tainan Park, Kaigen Temple }\end{array}$ \\
\hline 14 & Takao-Heitō-Takao & $\begin{array}{l}\text { Heitō Park, Taiwan Sugar Heitō factory, Takao Port, } \\
\text { Lighthouse, Mt Hōtai }\end{array}$ \\
\hline 15 & Hokutō & Hokutō hot spring, Fudō Falls \\
\hline 16 & Hokutō-Taihoku-Kiryū & $\begin{array}{l}\text { Port under construction, Sharyō Island, Courbet's Beach, } \\
\text { Senton Cave }\end{array}$ \\
\hline 17 & At Sea & [none] \\
\hline 18 & At Sea & [none] \\
\hline 19 & At Sea & [none] \\
\hline 20 & Kōbe & [none] \\
\hline 21 & Tokyo & [none] \\
\hline
\end{tabular}

SOURCE: Japan Tourist Bureau, ed., Ryotei to hiyō gaisan Taishō 12-nen (Tokyo: Japan Tourist Bureau, 1923), 287-95. 
meant to capture something else-generally a site of production or circulation. The one exception to this rule was the Government General of Taiwan, which featured images of "native customs" from at least 1916 on, as well as a recommendation to visit the "tamed" indigenous village of Kappanzan (C. Jiaobanshan). On the broad scale, however, colonial boosters did not encourage what we have come to know as "ethnic tourism," in which "the native is not simply 'there' to serve the needs of the tourist; he is himself 'on show, a living spectacle to be scrutinized, photographed, tape recorded, and interacted with in some particular ways." ${ }^{38}$

The omission of any discussion of colonized cultures or peoples is particularly curious in the context of the widely publicized and debated assimilation policy (dōka) in both Korea and Taiwan, which was predicated on long-running scholarly and popular discourses about the backwardness and savagery of Koreans, Taiwanese indigenous peoples, and Chinese people in both Taiwan and China-the same discourses that legitimated the political and legal distinctions between the inner territory and the new territories. Yet the Bureau of Railways argued that Japanese-language tourist guidebooks did not need to include information on colonized subjects. In the preface to its 1919 translation of the Korea, Manchuria, and China volumes of the Official Guide, the Bureau of Railways explained that, "For readers from the United States and Europe, it was particularly necessary to provide explanations of such things as the conditions of countries (kokujō) and customs. But the general Japanese traveler does not necessarily require [such explanations], and, as such, we have omitted them." ${ }^{39}$ In the end, colonial boosters presumed the imperial traveling public to be entirely too familiar with the customs and character of Koreans, Chinese, Taiwanese Chinese, and Taiwan's indigenous peoples, and thought that they might prefer to learn about the land and its contents instead.

Colonial boosters used tourist guidebooks and itineraries to convince Japanese travelers of the success of Japanese colonialism and the legitimacy of Japan's claims to colonized land. Central to this argument was the idea that the place of colonized land could be distinguished from the place of colonized people. In other words, that it was possible to describe parts of Korea, Manchuria, and Taiwan as "like the inner territory" at the same time that one described the colonized peoples who occupied that land as "out of place in this world." To make this argument, tourist guidebooks and itineraries used three modes to define the place of colonized lands: the economic mode, with its emphasis on sites of production and circulation; the historical mode, which narrated the past of colonized lands as linear histories of transition from primitive existence to unified states and then to incorporation into Japan; and the nationalist mode, which located colonized lands within the affective space of the national land and a collectively experienced national past. Each of these modes instructed travelers to understand the place of the land as a matter of location within global networks of exchange, developmental time, and the history of the colonizing nation. Not part of these representations of colonized land were 
concepts of place as essence or of place as a specific cultural region. Rather, tourist guidebooks and itineraries treated the place of colonized lands as malleable. Moreover, the modes overlapped in contradictory ways, which kept the place of colonized lands liminal-always both within and without the space of the nation.

\section{PORTS, PRODUCTS, AND THE CIRCULATING MISSION}

In teaching Japanese travelers to see the territories of Taiwan and Korea as part of Japan, and Manchuria as not a part of China, the colonial governments and the South Manchuria Railway Company directed travelers' attention to the infrastructure of circulation and production. They portrayed Japanese imperialism as a "circulating mission" as well as a "civilizing" one. By the mid 1910s, new ports, railway lines, and steamship services had integrated the metropole and the new territories into a smoothly operating transportation network. Sites of circulation, such as bridges, wharves, and vehicles themselves, and sites of production, such as coal mines and sugar factories, featured heavily in the colonial governments' and South Manchuria Railway Company's representations of their own achievements in transforming the new territories into part of a new Japan..$^{\circ}$ Blurring the boundaries between metropole and colony, these guidebooks argued that not only had the new territories been fully integrated into metropolitan circuits of production and exchange but also, through the intervention of Japanese colonialism, they were now significant places in their own right within the global market.

Tourist guidebooks and itineraries gave ports special consideration as gateways: sites where colonial boosters could contrast the smooth movement of goods and people between territories with the imagined isolation of the pre-colonial landscape. Pusan, for example, was a testament to the progress of the Government General of Korea's Japanification project. The 1923 Chōsen tetsudō ryokō benran (Quick guide to railway travel in Korea) painted a picture of the port in words, explaining how development under the Government General of Korea had transformed Pusan into a mirror of Japan: "Like a mirror, you see the crowd of steamships and sailboats, and the scene of the town with buildings lined up from the shore to the mountainside, and wonder if you are again looking at Shimonoseki or Moji [the two neighboring ports from which the connecting ferry departed]." ${ }^{41}$ The 1921 Chōsen tetsudō ryokō annai put it more succinctly: "Pusan has been so Japanified, it doesn't even smell like Korea anymore." 42

In fact, few cities in Japan boasted the size and facilities of the port of Pusan. Rural areas, particularly in the northeast, lagged far behind major cities in any part of the empire in terms of electrification and urban modernization. Tōhoku, for example, in the northeast of the main island of Honshū, received startlingly little of the infrastructure development dollars that benefited the nation's more urban 
areas. In 1930, for example, there were fifty-seven electric light bulbs for every one hundred people nationally; there were only thirty-four per hundred people in Tōhoku. As the decade progressed, the disparity worsened. By 1935, Tokyo boasted more than one light bulb per person while Tōhoku actually lost light bulbs. ${ }^{43}$ In other words, the process that the Government General wished travelers to see as "Japanification" had little to do with an actually existing Japan. Rather, colonial boosters used geographic signifiers to place Korea within an imaginary Japan that they defined as a space of industrialization and circulation.

Although the term "Japanification" was rarely used outside of Korea, official guidebooks and itineraries for Taiwan and Manchuria followed a similar strategy for placing these territories firmly within an economic space of empire defined not by inside and outside or advanced and backward, but by production and circulation. Sites of connection, such as ports and bridges, showed travelers a map of Japan shaped by transport rather than geographic barriers. And though there was little commentary on the destination of colonial products, the heavy emphasis on production demonstrated how colonial territory was flourishing under Japanese management.

As the port of arrival and departure for the Osaka Mercantile Shipping Company's regular service to the Japanese port of Moji, the port of Kiryū (C. Jilong; E. Keelung) was a routine stop for imperial travelers arriving at and departing Taiwan. Eager to highlight the Government General of Taiwan's efforts to bring Taiwan into the world of industrial movement, JTB itineraries explicitly labeled the "renovations to the port of Kiryū" as a sight to be seen. ${ }^{44}$ With railways that ran right to the docks, the 1921 Taiwan tetsudo ryokō annai (Guide to railway travel in Taiwan) reported the new port of Kiryū was "very convenient for connections between land and sea travel." Making clear the role of the colonies in the construction of a new Japan (and thus going beyond what the Japanification of Pusan implied), the guidebook helped travelers to see the port in comparison: such a convenient land-sea connection was "perhaps something rarely seen in our country" 45 A new Japan was being born-in colonial territory.

Although Manchuria was an informal rather than formal Japanese colony, the South Manchuria Railway Company's Passenger Bureau pursued a strategy similar to that of the Governments General of Taiwan and Korea. Guidebooks for southern Manchuria began with Dairen, which the South Manchuria Railway Company ensured would be the most active port in Manchuria through its policy of "Dairen centrism" (Dairen chüshinshugi). ${ }^{46}$ Dairen was the key port for the transshipment of Manchurian goods and the headquarters of the South Manchuria Railway Company. As the 1909 Minami Manshū tetsudō annai (Guide to railways in southern Manchuria) described it, however, the wharf at Dairen was emblematic of the whole of Japanese-controlled Manchuria itself; it was "a grand construction project" whose "vast scale" made it a "rare sight in the Orient." ${ }^{77}$ For 
some travelers, the wharf marked Dairen as a place that was no longer in Asia or China, but rather served as a gateway between the West and the East. As one of the Hiroshima Higher Normal School diarists described it, Dairen was the "Marseilles of the Orient," a reference to Marseilles' role as the gateway between France and North Africa. ${ }^{48}$ The wharf was so central to the railway company's promotion of southern Manchuria that the first image included in the 1909 guidebook was a pullout panoramic photo of the wharf-showing clearly the railway that connected the piers to the wharf and three steamships tied alongside. In later editions, the South Manchuria Railway Company used a line drawing of a steamer tied up to the pier at Dairen as the guidebook's inside cover (see the cover of this book).

While ports showed the efforts of the South Manchuria Railway Company and the Governments General to bring the new territories into the pathways of modern circulation, sights inside the colonies showed travelers the resources that Japanese industries were turning into valuable commodities. Early guidebooks and itineraries placed commodities front and center. Itineraries for Taiwan reflected the colonial government's vision of Taiwan as an agricultural appendage of Japan. The JTB's 1923 itinerary for Taiwan, which required three weeks, sent travelers on a journey through Taiwan's raw materials and industrial production sites. At each stop, the itinerary suggested seeing sights of industrial and agricultural modernization. In Taichū (C. Taichung), travelers were to see Imperial Sugar's Taichū factory. In Hokkō (C. Beigang), the sight to see was Oriental Sugar's Hokkō Factory. In Heitō (C: Pingtung), Taiwan Sugar's Heitō factory. Other forms of industrial production dotted the remainder of the itinerary, from the Eirinjo Timber Factory in Kagi to the salt flats at Takao (see table 2). The Government General of Taiwan's 1916 Taiwan tetsudō ryokō annai underlined the significance of these sights with data that described the volume of production at each factory and gave a description of the "major products" of the area that surrounded each station stop. All told, administration, sugar factories, and industrial agriculture constituted nearly sixty percent of all the sights noted by the 1916 guidebook. ${ }^{49}$

To further promote these sights, the Government General of Taiwan's guidebooks highlighted the high levels of productivity of sugar and timber factories. The description provided by the Government General was concise, defining as quickly as possible the power of the new productive infrastructure. In Kagi, the main sight to be seen was the Kagi Timber Factory, which operated the "latest machinery to process timber from Mount Ari." ${ }_{50}$ Photos included alongside showed a large, Spartan factory poised on open flatland next to a railway line. Imperial Sugar's factory at Taichū was "capitalized at five million yen and could run at 1,050 horsepower." In 1916, the guidebook reported that the factory had produced fifteen thousand tons of sugar in the most recent season..$^{51}$ Subsequent editions did little to elaborate on the merits of each sugar factory, except to note a staggering increase in sugar production. Taiwan Sugar's Heitō factory, which consolidated sugar from 


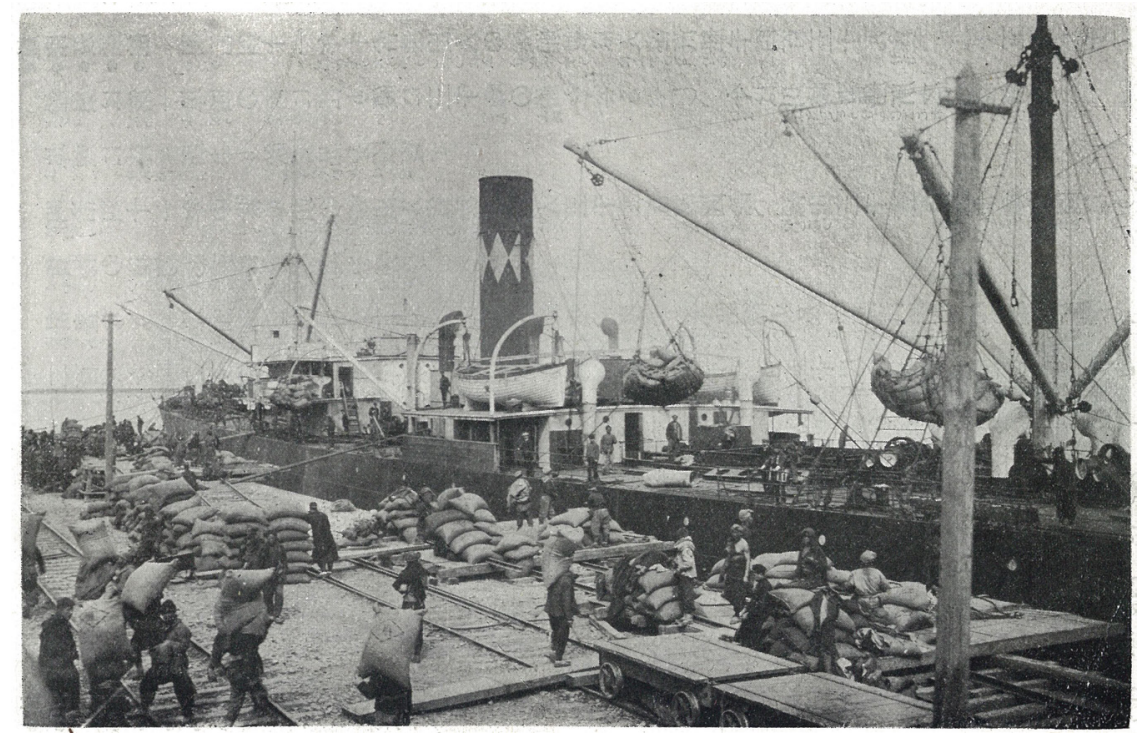

FIGURE 4. The loading of soybeans at Dairen wharf. The picture accompanied the South Manchuria Railway Company's 1909 description of Dairen wharf. It shows the three tracks of the dock railway, a ship that runs almost the length of the wharf itself, and dozens of Chinese laborers carrying and stacking hundreds of bags of soybeans. The sight to be seen was the transport of goods, not the people.

SOURCE: Minami Manshū tetsudō kabushiki kaisha, ed., Minami Manshū tetsudō annai (Dairen: Minami Manshū tetsudō kabushiki kaisha, 1909).

all of Taiwan Sugar's local factories, produced forty-five million tons of sugar in $1926 .{ }^{22}$ Dai Nihon Sugar's Hokkō factory, nearby, produced over thirty million tons the same year. ${ }^{53}$

If sugar and timber evidenced Taiwan's place in a global market as well as a Japanese economy, soybeans and coal defined Manchuria in similar terms. Beginning with the first South Manchuria Railway Company guide in 1909 and continuing through each subsequent edition, the soybean dominated the representation of Manchuria's unique place within the world. The 1919 edition included photos of stacks of soybean cakes ("the collection and distribution of soybean cake") and a vast warehouse full of bags of soybeans..$^{54}$ In addition to seeing the soybeans ready for export at the wharf, travelers were also encouraged to visit one or more of the nearby soybean oil factories, sixteen of which were noted on the guidebook's map of Dairen. The Tokyo Number One Higher School made its first stop at the soybean warehouse in Dairen in 1912. The size of the warehouse impressed the student diarist enough that he quoted how many beans per square foot it could hold. 55 
Second to soybeans in South Manchuria Railway Company guidebooks was coal. The production of coal centered on Bujun (C. Fushun), the central colliery of Manchuria and one of the South Manchuria Railway Company's major industrial enterprises in Manchuria. ${ }^{56}$ Here, the rhetoric of Japan's leadership in the production and circulation of commodities continued. The sights to be seen in Bujun were sooty, loud, and industrial. The South Manchuria Railway Company included Bujun in all its itineraries, and its guidebooks included images of the smoking Mondo Tile Factory, coal elevators above the underground mines, and a "sand-gathering machine" on the banks of a nearby river. The 1919 guidebook devoted a number of pages to describing the investment the South Manchuria Railway Company had made in increasing the efficiency and productivity of the mines, contrasting this with the "makeshift" methods employed under the Russian China Eastern Railway. The guidebook also detailed the South Manchuria Railway Company's past interventions and outlined plans for the further economization of mining operations. The mines had once produced only three to four hundred tons a day, but by 1919 the mines were producing seven thousand tons a day. "Bujun," the guidebook concluded, "is on the verge of becoming a great industrial area." ${ }^{57}$

\section{JAPANIFICATION}

In contrast to the economic mode, which described Korea, Taiwan, and Manchuria as places within a space that was defined sometimes as "like Japan," sometimes as "civilization," and sometimes as "like the West," guidebooks used the national and historical modes to place colonized lands within the space of the Japanese nation. From the first days of imperial travel, battlefields were sites where travelers were encouraged to experience colonized lands as national land through emotional narratives of patriotic sacrifice. This was true even in Manchuria, which was not part of the sovereign territory of Japan (see chapter 1). Early tourist guidebooks and itineraries expanded the nationalist mode to include Shintō shrines, which helped travelers to situate the new territories within a form of spirituality that Japanese ideologues portrayed as uniquely associated with the Japanese state. Colonial shrines often housed gods associated with empire. For example, the Taiwan Shrine in Taihoku (C. Taipei) housed the "three gods of exploitation" (kaitaku sanjin), who had first been deified in the establishment of a shrine in Hokkaidō, and the spirit of Prince Kitashirakawa as a "protector deity" of the nation..$^{8}$ Prince Kitashirakawa had been a celebrity of the campaign to subdue Taiwan after the transfer of sovereignty in 1895 . The popular illustrated magazine Fūzoku gahō (Customs illustrated), for example, exulted in his daring exploits against the guerrilla resistance in its pages. After his death, the cause of his celebrity shifted from military prowess to martyrdom. In a practice similar to that of the reenactment of Russo-Japanese War battles in Port Arthur, the Government General of Taiwan's guidebooks 


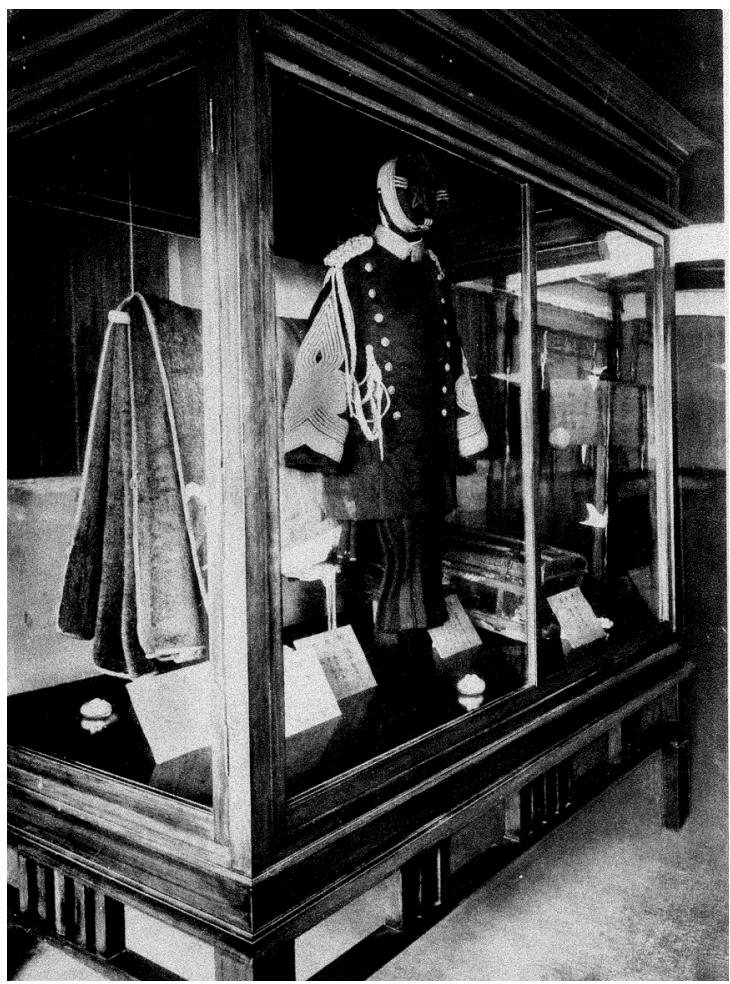

FIGURE 5. Kitashirakawa's uniform on display at Tainan Shrine. The uniform was one of several items related to Kitashirakawa that Government-General tourist guidebooks suggested imperial travelers see on their tours of Taiwan. Like this uniform, each item on the "trail of Prince Kitashirakawa" was described as one that Kitashirakawa "really" (jissai ni) used prior to his death in Taiwan in 1896. SOURCE: Tainan jinja shamusho, ed., Tainan jinjashi (Taihoku: Tainan jinja shamusho, 1928).

encouraged travelers to follow the "trail of Prince Kitashirakawa" to see places that he "actually" slept, traveled, and died on Taiwan, especially Tainan Shrine. 59

Just as shrines and battlefield sites encouraged travelers to use the verisimilitude of their locations to reenact a national past and reflect on a national spirit, guidebooks and itineraries likewise used historical sights to encourage travelers to observe the process of historical transition from non-modernity to modernity and from non-Japanese to Japanese rule. They adopted strategies that made the past of each place comprehensible in terms of a linear narrative of unification and incorporation into Japan. Beginning with the first tourist guidebooks and continuing to the end of the empire, the colonial governments and the South Manchuria Railway 
Company gave Korea, Manchuria and Taiwan a historical character by assigning each an ancient and a modern capital.

More so than guidebooks for Taiwan and Manchuria, guidebooks for Korea emphasized historical sights. To a certain extent, this emphasis reflected the differences between the policies of the Government General of Taiwan and the South Manchuria Railway Company, the former of which worked to transform Taiwan into a source of agricultural products to feed the growing industrial workforce in the metropole, and the latter of which, in lieu of sovereignty, focused on anchoring Japan's claim to Manchuria in its "management" of the region's human and material resources for the benefit of the global market. But the emphasis on historical sights in Korea also reflected the colonial discourses circulating at the time. While Taiwanese Chinese people in Taiwan and Chinese people in Manchuria might have been members of an East Asian cultural sphere that Japanese ideologues defined as "same script, same race" (dōbun dōshu), Japanese colonial discourse depicted Koreans as people who also shared a common ancestry with the Japanese. For colonial discourse on Korea, the challenge was to explain how the outcomes of two nations, which were in theory composed of the same people, were so different-one an empire, one a colony. In contrast, Manchuria and Taiwan were described as vast, untapped territories that had been colonized only recently by the Chinese. The emphasis in these cases was on differentiating Japanese colonialism from the Chinese and European colonialism that had come before. Thus, in Taiwan, the ancient capital of Tainan (C. Tainan) and the modern capital of Taihoku served as the two poles of recorded insular history. In tourist materials, the two capitals told the story of the shift from a Dutch and Chinese imperialism that sought to benefit only itself to a Japanese imperialism that benefited "the whole island." ${ }^{\circ}$ In Manchuria, the two halves of the city of Hōten-one "Chinese" and old, the other simply "new" - served as the ancient and the modern capitals of Manchuria, describing the city's arc from capital of the Manchus to a dusty, forgotten city - when the Manchu rulers became the Qing emperors in Peking-and then to the forefront of the modernization of East Asia with the Japanese construction of the new city. ${ }^{61}$

Placing the territories in developmental time naturalized imperialism by normalizing transition. In the case of Korea, the guidebooks identified five historic capitals of Korea-Puyo (K. Buyŏ), Keishū (K. Kyŏngju), Keijō, Kaijō (K. Kaesŏng), and Heijō. The Government General's guidebooks used the multiple capitals to underscore the argument that Koreans had failed to develop successfully as a people because they suffered from too many transitions. This failure was constituted, always, in contrast to the successful development that Japan had experienced due to its supposedly unbroken imperial line.

Overlaid on the narrative of multiple transitions was the story of how Korea became part of the Japanese state. The Government General of Korea's guidebooks 


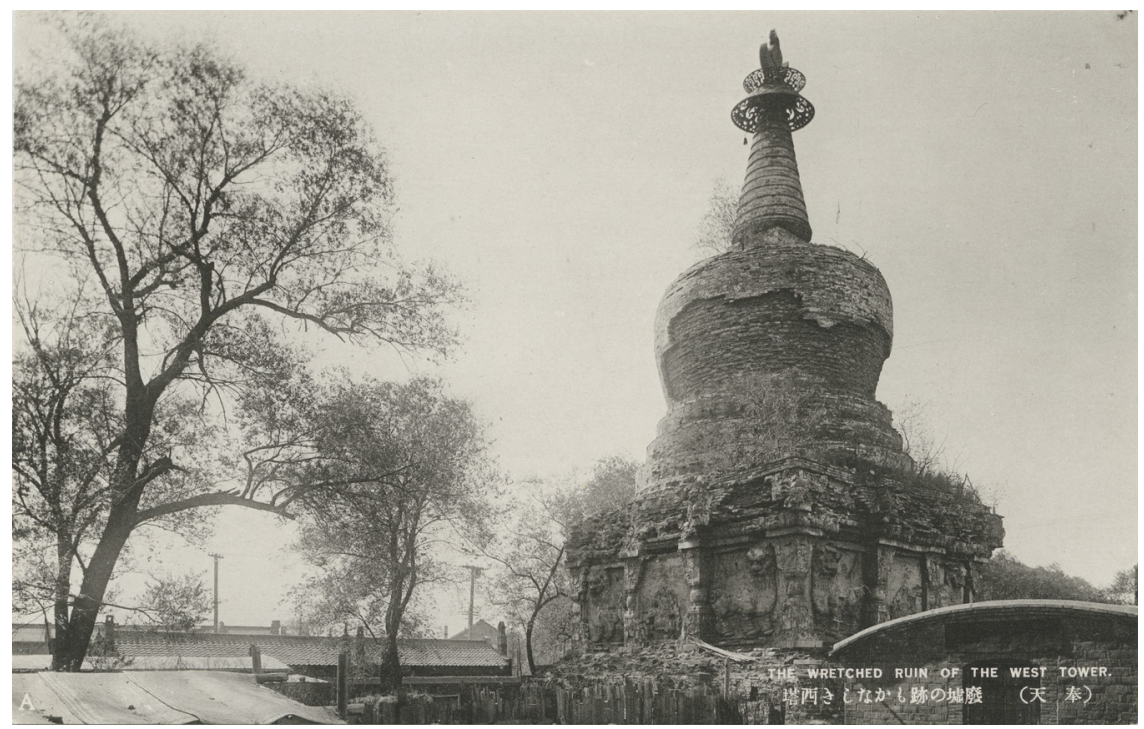

Figure 6. "The Wretched Ruin of the West Tower." Postcard, c. 1910s. The South Manchuria Railway Company used historical sights, such as the West Tower, to tell a story of Manchuria's historical abandonment by the Manchus. Together with the former Manchu palace inside Hōten's city walls, colonial boosters' used the West Tower to describe the early glory of the Manchu rulers and the subsequent decline of their infrastructure after they left Hōten for Peking, where they ruled as the emperors of the Qing dynasty (1644-1912). Historical narratives such as these served to justify colonial boosters' claim that Manchuria was not an authentic part of China. Digital image courtesy of the East Asia Image Collection, Lafayette College Libraries, Easton, PA. Image ipoo84.

paired Heijō and Keijō as "ancient" and "modern" capitals to reify a narrative of development and transition that culminated in the "annexation" of Korea and the reunion of the Korean and Japanese peoples. The guidebooks presented Keijo, the first major stop after arriving at Pusan, as a grand vista of peninsular history, from the early history of the Paekche kingdom to the transfer of power to the Government General in 1910. Layered among the city's many sights were ruins and remains of three dynasties, as well as the new infrastructure that made the city the "capital of the peninsula," a reference that sought to remove the city from the connotations of feudalism that came with the name "Chōsen." ${ }^{2}$ But despite the thousands of years of peninsular political history in the city, the significance of all of it was exceeded by the Chosŏn dynasty (1392-1910) - the last dynasty prior to the annexation by Japan. Of nineteen sights listed by the 1921 Chōsen tetsudō ryoko annai, only one traced its significance solely to the Paekche. ${ }^{63}$ Rather, the 
guidebook's suggestions centered on sights related to Chosŏn dynasty and colonial rule: the Chandŏkkung and Kyŏngbokkung palaces, government buildings, Independence Gate, tombs of the Chosŏn dynasty's ruling Yi family, and sites of enthronement and conflict.

The tourist guidebooks rarely described Chosŏn dynasty sights as impressive in their own right; they valued them for the story they told of the transition to Japanese colonial rule. For example, although in 1921 the Government General headquarters was still located in the former headquarters of the Resident General, an ornate Victorian building in the Japanese settlers' quarters, the 1921 guidebook stressed that Kyŏngbokkung, the palace of the Chosŏn dynasty, was going to be the new headquarters of the Government General of Korea. This practice of layering the new Japanese government over the previous Chosŏn dynasty included Japanifying the palace's name: "Keifukukyū: Although the new Government General office is now under construction here, this place is the first palace where the founder of the Chosonn dynasty undertook the great work of rule." ${ }^{64}$

Other Chosŏn dynasty sites, such as the Ch'andŏkkung Palace, were similarly made to speak to the transition from Chosŏn to Japanese rule. In its description of Chandŏkkung, a residence for the Yi family, the 1921 guidebook described the layout of the palace and then quickly moved to the botanical gardens, zoo, and museum, which were located on the palace grounds. These areas, the guidebook pointed out, used to be part of the secret gardens of the Chandŏk Palace, "but are now opened to the public" (kōkai sareteiru). ${ }^{65}$ As Noriko Aso argues, the creation of public spaces connected with the imperial families was a key component of official narratives of modernization in both Korea and Japan. ${ }^{66}$ Such notions were popular in urban planning, from the transformation of Tokyo into a modern capital in the late nineteenth century, to the Great Han Empire's push to the reform the space of Hwangsŏng, the city that would become Keijō under Japanese rule, "to create a symbolic national center from and through which to integrate the previously stratified groups of Koreans into national subjects of King Kojong." ${ }^{37}$

In the colonial context, tourist guidebooks used the conversion of private space into public space to construct a narrative of historical transition to a modern society that was Japanese in terms of its language and state but was universal in its embrace of the free circulation of people, goods, and ideas. In this formulation, what distinguished Japan, and the modern nation-state more generally, from the politics that had come before was that modern government was a public good. Indeed, in the historical overview that preceded the description of what to see in Keijo, the guidebook portrayed the transition from the Chosonn dynasty to the Government General not so much as one of political turnover but of the next stage in the development of government on the peninsula: "From [the establishment of the first Chosonn palace in Keijō] over five hundred years ago, the palace and the city have been rebuilt countless times after fires and disturbances. Yet its 


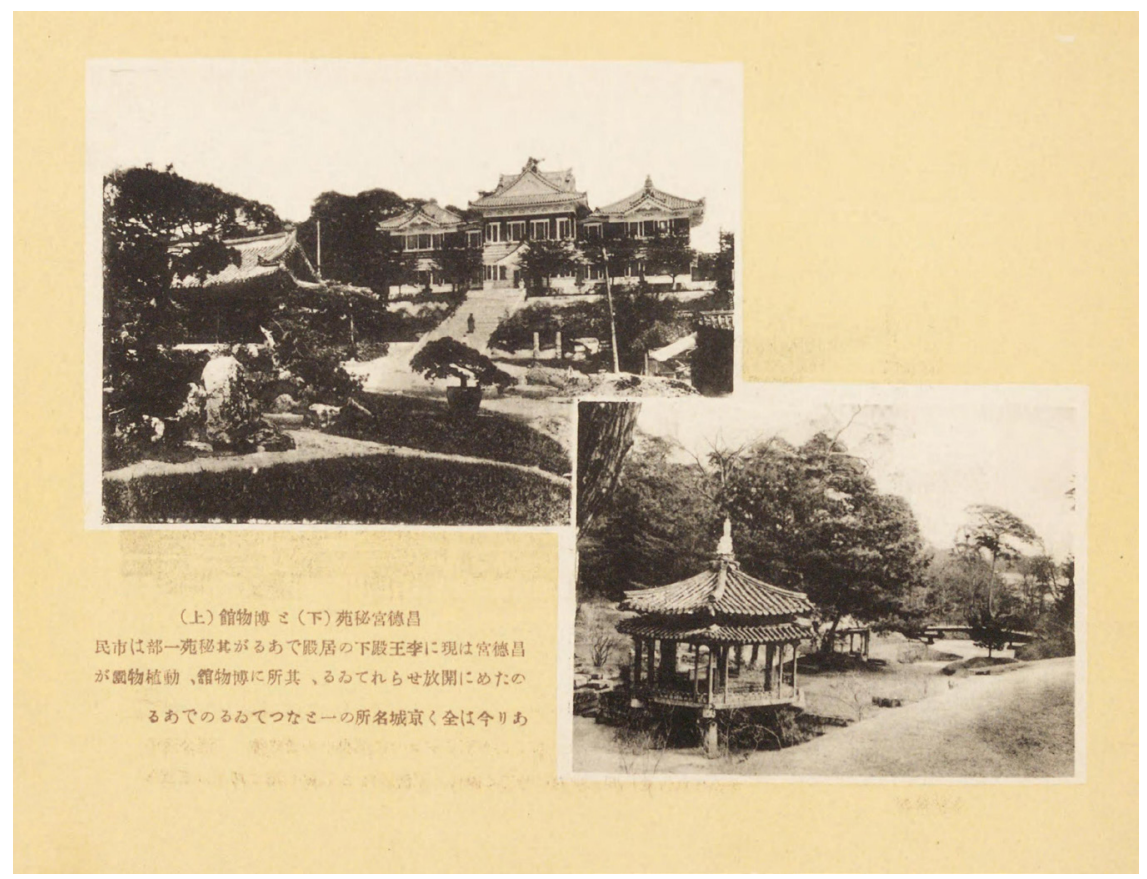

FIGURE 7. The Government General Museum (above left) and "Secret Garden" (below right) at Chandǒk Palace. The caption explains that although the gardens were actually the residence of the Yi royal family, a part of the gardens had been opened to the public. The vertical placement of the images of the garden and the museum provides a visual narrative of the transition from private to public resources that the Government General argued characterized Japanese colonial rule in Korea.

source: Minami Manshū tetsudō kabushiki kaisha Keijō kanrikyoku, Chōsen no fūkōo ([Keijō]: Minami Manshū tetsudō kabushiki kaisha Keijō kanrikyoku, 1922). Courtesy of the National Diet Library.

prosperity as the capital of the peninsula has never changed. In particular, the last ten or so years have shown surprisingly rapid progress (chōsoku no shimpo) and expansion." ${ }^{88}$ Without even mentioning the Government General, Keijō was made to demonstrate the long history of unified rule over the peninsula and, most importantly, the grand achievements that had come in the past ten years with the transition to colonial rule.

The path of the express railway arranged travelers' encounters with Korea such that Heijō, the "ancient capital" (koto), immediately followed Keijō, the "capital of the peninsula." As the former capital of multiple dynasties but present capital of none, the role Heijo played in the progress of peninsular history was more ambiguous than that of Keijō, which had the presence of the Government General 
and the last unified peninsular dynasty to demonstrate the orderly transition of rule. In Heijō, the Government General used the city's history to undercut Korean nationalists' claim that Koreans were an independent ethnic nation. The sights of Heijo emphasized the ambiguity of the origins of the Korean nation and linked the ancient history of "the country of Chōsen" (Chōsenkoku) to tributary relations with China. For all the talk of Heijōs turbulent ancient history, however, the sights the guidebook recommended ultimately told an overarching story similar to that of Keijō: the transition to Japanese rule, in this case not from independent Korean dynasties but from Chinese to Japanese influence. In this, it was a distinctly state-oriented narrative of origin and transition rather than an ethnicity-oriented narrative, in contrast to those put forth by Korean nationalists such as Sin Chae-ho. ${ }^{69}$

As an "ancient capital," the guidebooks made Heijō embody the heterogeneous origins of Korea as a unified political territory and celebrate the transition from Chinese to Japanese rule as a result of Japan's victory in the 1894-95 Sino-Japanese War. As the 1921 entry on Heijō began, "Ages ago, the people of the country enthroned the god Tan'gun, who had been born under a spindletree on Mount Paektu, and made a capital at Heijō. Thus, from a mysterious legend begins the history of this place." The first recorded history cited by the guide dated from the time of the Zhou dynasty (1046-256 BCE), "when it is said that a branch of the Kishi family moved to Chōsen and made Heijō their capital." The founding of the first historic Korean capital by a Chinese nobleman was confirmed, the guidebook continued, by the true history of the Song dynasty (960-1279 CE): "Ryōyō Province, from olden times [known as] 'the country of Chōsen,' is a place that was ruled by Kishi. Today's Chōsen probably took the old name." ${ }^{\circ 0}$ The historical overview continued to emphasize the turbulence of Heijō's history as capital: Heijō ceased to be the capital of Kishi (K. Kija) Chōsen when the descendants died during the time of the Han empire (206 BCE-220 CE); the Han established the Lelang Commandery (108 BCE-313 CE), but were eventually thrown out by the Koguryŏ (37 BCE-668 $\mathrm{CE}$ ); following the fall of the Koguryŏ, Heijo became a western capital for the Koryŏ (918-1392 CE), under many names. To emphasize further the changing fortunes of Heijō, the overview concluded with a literary read on the city's main river, the Daidō (K. Taedong): "[And the blue Daidō river] looks as if it holds the secrets of antiquity and is sneering at the glory and decline of the human world." ${ }^{71}$

Subsequently, Heijō was the site of encounters of Japanese and Chinese armies during Hideyoshi's sixteenth century invasions of Korea and the 1894-95 Sino-Japanese War. Indeed, the majority of the city's sights told the story of Konishi Yukinaga's defeat by the Ming army in the Bunroku campaign (1592), and the Japanese army's rout of the Qing army in 1895. Renkōtei (K. Ryŏngwangjŏng), a pavilion dating from the Koguryŏ era, was the site "where Konishi Yukinaga fell into the trap of the sinister scheme of Ming Ambassador Shen Weijing" during the 
Bunroku Campaign, which "was the basis for his crushing defeat at Heijō" ${ }^{72}$ The "sinister scheme" referred to the secret drugging of the commander of the Japanese army defending Heijo by a Korean courtesan. The sleepy commander was then beheaded by the leader of the Ming army, and Japanese forces were forced to retreat. Similarly, Otsumitsudai (K. Eulmildae), a pavilion also dating to the Koguryŏ era, was where "the enemy made ... their stronghold and hung their uniforms on the tree branches to make dummy troops and menace Yukinaga" during the Bunroku campaign. Botandai (K. Morandae), a neighboring pavilion, was where Konishi Yukinaga "put his main headquarters and sucked up the pain of a defensive battle" when "he found himself surrounded by the Ming army."

Neighboring these sights that staged the loss to Ming China were the sights that told the story of Japan's eventual victory over Qing China. The Futsū Gate (K. Pot'onmun), a nine-hundred-year-old gate that dated to the Koryŏ period, was where the Ming army entered the castle walls of Heijo to begin the battle with Konishi Yukinaga's forces. Three hundred years later, it was the site from which one battalion of Japanese forces attacked the Qing army during the Sino-Japanese War. The Shichisei Gate (K. Ch'ilsŏnmun) marked the northern entrance to the castle and had been the site of pitched battles in both the Bunroku campaign and the Sino-Japanese War. During the Sino-Japanese War, Qing troops took the high ground and "rained down" an attack on the Japanese army. Otsumitsudai and Botandai, which were famous as sites of defeat during the Bunroku campaign, served double-duty as sights of glorious victory during the Sino-Japanese War. At Otsumitsudai, "the Qing General made this his headquarters, where he was made to worry about the two [incoming Japanese] army branches from Gensan." Previously well known as the site of Yukinaga's "painful" defensive battle against the Ming, Botandai became the site of a "famous struggle" during the Sino-Japanese War and the source of a "new memory for the world." 74

\section{IN PLACE / OUT OF PLACE}

In their efforts to rehabilitate Korea, Manchuria, and Taiwan in the metropolitan imagination, colonial boosters used similar strategies to place colonized lands within the space of civilization and the space of the nation. The histories told were explicitly not the histories of the colonies' ethnic nations. The South Manchuria Railway Company guidebooks, for instance, had no interest in Han Chinese residents, other than to represent them as cogs in the machine of soybean and coal production and circulation. Similarly, the state-centric story of Korean origins disconnected Korea from Koreans and therefore from the progressive history of the peninsula. Despite some small-scale discussion of the "native customs" and "tamed villages" of Taiwan's indigenous peoples, Taiwan's history was restricted to the narrative of transition from the ancient capital of Tainan to Taihoku, limiting 
the story to the western, plains areas of the island and erasing indigenous people from the island's history, which was now told as a progression of Dutch, Spanish, Chinese, and then Japanese colonial rule.

The economic, historical, and nationalist modes displaced and dislocated colonized subjects from the spatial and social imaginary of the nation by disconnecting their pasts and futures from that of the land. But this is not to say that colonized subjects were tangential to the project of placing colonized lands within the nation and the nation on colonized lands. Their labor was essential to the operation of civilization's modern transportation infrastructure. From the Chinese conductors of South Manchuria Railway Company streetcars in Dairen to Korean and Chinese construction workers, miners, and farmers, and those who moved goods from the railhead to the city, the networks of exchange simply could not have functioned without their labor. ${ }^{75}$ Moreover, the figure of the colonized subject played a significant role in defining travelers' experiences of the colonies as places that were becoming part of the space of the nation. Like colonial boosters, imperial travelers used the historical, economic, and nationalist modes to define their own sense of belonging, or "in-placeness," in Korea, Manchuria, and Taiwan, while using these same modes to mark colonized subjects as out of place.

For imperial travelers, these modes structured their imagination of a normative landscape of the nation, which was reified through the contrast between the ideals that the modes professed and the colonized subjects they saw. ${ }^{76}$ Arakawa Seijirō, who traveled to Manchuria and Korea as part of a 1918 tour of businessmen from Utsunomiya, used a scene at the Manchurian port of Eikō (C. Yingkou) to illustrate the incongruity of Chinese people in spaces of circulation, embodied in this case by the railroads. He compared the Chinese Government Railways station with the South Manchuria Railway Company's Eikō Station. The South Manchuria Railway Company's station had been bustling. But the Chinese station was different: "There didn't seem to be even one person in charge at the station. . . Two or three people came in noisily, but even so there didn't seem to be any passengers." There was only one soldier "lumbering" around with his gun." In Keijō, Koreans appeared out of place in the modernizing peninsula. As one imperial traveler wrote in a 1915 report: "When I look at Koreans walking through the Japanified town, it seems like somehow they are a race (jinshu) that has come from another country." ${ }^{88}$ The poet Kawahigashi Hekigotō described the out-of-placeness of Koreans more bluntly. It was not that "Korea falls, but at least there are mountains and rivers," he wrote. Rather, referring to the common colonial practice of denigrating Korean men for their clothing, Kawahigashi thought the process was more akin to "the country dies, and there remain outstanding clothes and hats."79

If, in the historical mode, out-of-placeness was determined by a failure to transition, in the economic mode, it was a failure to organize one's life or society around the principles of circulation, exchange, investment, or the production of 
value. Nagasawa Sokichi, a speaker of the House of Representatives who toured eastern Taiwan in 1916, explained that indigenous people misunderstood the purpose of money. Describing a situation closer to slavery than wage labor, Nagasawa noted that "recently, because of labor shortages, sugar companies and the like don't even bother with offering to employ the savages (banjin), since if they request [indigenous labor] from the police, the savages will do whatever the police say. They come from each village like forced labor." But he explained that sugar companies used compulsory labor not to exploit indigenous people but because indigenous people were unable to grasp the value of the money. "If you try to pay them with paper money, they won't take it," Nagasawa wrote, because "they fear that it will rot." The solution was to try to pay them in silver coins, but even this did not work: "They use them to do things like dig holes, decorate their necks, or to decorate their swords by driving them in [to the handle]. They do this because they don't understand that [money] is used as a medium of exchange." ${ }^{\circ}$

The student diarist for the Hiroshima Higher Normal School dwelled similarly on how the failure to understand concepts such as "investment" could lead to rapid changes of fate. In Hōten, he remarked, "nobody can avoid thinking of the last days of the Qing." ${ }^{11}$ When the students visited the Northern Tomb in Hōten, however, they placed the blame for its fragile state not on the vicissitudes of history but on the failure of the Chinese nation as a whole to embrace investment. "If it's not actually about to crumble, the Chinese won't fix it," the diarist explained. ${ }^{82}$ Hayasaka Yoshio, another resident of Tochigi Prefecture's Utsunomiya City, who published an account of his travel through Korea, Manchuria, China, and Taiwan in 1922, used an encounter with Korean rickshaw pullers in Keijō to likewise condemn the Korean people. Hayasaka recounted how he asked two different rickshaw pullers for a ride to the Higher Common School, only succeeding after walking a considerable distance and trying for a third time. "What does the above story tell us? If I were to put it in one word, I would say that it shows the laziness (taidasei) of the Korean people," he wrote. What Hayasaka called "laziness" was not an unwillingness to work; it was an unwillingness to plan ahead. "Their level of living is extremely low, and if they earn enough to live for one day they sleep or drink or eat or gamble. Tomorrow's matters are tomorrow's, and next year's matters can be dealt with next year." ${ }^{3}$

Yoshino Sakuzō, Japan's most famous prewar liberal, summed up how colonized subjects' failure to join the modern world of investment and exchange necessitated Japanese stewardship over their lands. In his 1916 report on Manchuria and Korea, he spelled out how important it was to recognize the gap between how Japanese settlers and officials understood the purpose of labor and how the "natives" (dojin) did. The Koreans he spoke to on his trip objected to the massive road construction projects being undertaken by the Government General, because the labor they were compelled to contribute was both unfair and bothersome. Yoshino 
did not agree with their claims. Nonetheless, he argued that it was important to take them into account when formulating colonial policy. "An ignorant people most certainly cannot endure losses today in the name of a long future of profit," he explained. While he agreed that it was "logical," when faced with these sorts of complaints, "to argue that the thoughts of the natives are mistaken," he advocated that colonial officials work with local Korean leaders to find a language that both sides would understand. "You can't govern the natives on logic," he concluded. ${ }^{84}$

Like most of the concepts and categories that structured colonial boosters' and imperial travelers' efforts to place colonized lands within the nation, the notion that colonized subjects were out of place in modern, industrial society, particularly in terms of attitudes toward circulation and labor, was not only a Japanese notion. In the entry on railways in his Things Japanese, for example, the early Japanologist Basil Hall Chamberlain wrote, "A railway journey in this country is apt to be anything but a joy."

Owing to some cause not yet explained, the Japanese who, when abiding in their own native ways, are the very pink of neatness, become slipshod, not to say dirty, when introduced to certain conditions of European life. ... In fact, the whole thing is queer and unpleasant, unless of course the traveler be a philosopher to whom every novel experience supplies welcome material for meditation. Such a philosopher will perhaps enquire the reason of the stripe of white paint across the windows of the third-class cars on certain lines. It is a precautionary measure adopted for the safety of country bumpkins; for it has happened that some of these, lacking in personal experience of glass, have mistaken it for air and gashed themselves horribly in the attempt to shove their heads through what, in their innocence, they supposed to be a non-resisting medium. ${ }^{85}$

Chamberlain's comments, like those of Japanese imperial travelers, were on par with how British travelers described railway transportation in Egypt and India. Nineteenth-century European imperialists argued that modern civilization and tradition occupied two different worlds: one, a world in which people used tools to dominate nature; the other, a world in which people lived according to nature's whims. The difference was psychological as much as material. There, British travelers treated the railway tracks as part of the space and time of the modern and the surrounding land as a completely separate territory in both space and time. ${ }^{86}$ On the same page that he noted that the arrival of "a dense crowd of natives" to an Indian train station provided "much that is amusing to a curious observer," G. O. Trevyelan observed that civilization and nature were like oil and water, never to share the same location. "Stroll one hundred yards from the [railway] embankment," he wrote, "and all symptoms of civilization have vanished." ${ }^{87}$

The point is that imperial travelers did not simply deny the coevalness of colonized subjects. They used their out-of-placeness as the measure against which they calculated the Japanification of the land. The "Japan" of Japanification was 
ambiguously territorialized - marked by generic industrial infrastructure and the sensibility of the observer as much as it was by cultural symbols such as Japanese place names or state-centered mnemonic sites. In this, colonial boosters enrolled imperial travelers in the project of constructing a spatial imaginary that contained the possibility of a floating "center" rather than one that would always be located in the inner territory. This practice constituted the problem of colonial difference as the out-of-placeness of colonized peoples and justified the incorporation of colonized lands in to the present space of nation.

Over time, the outbreak of anti-imperial nationalist movements and boosters' own frustrations with the uneven structure of colonial rule would force imperial travelers and colonial boosters to find ways to place colonized peoples within the space of the nation if they were to maintain the place of the nation on colonized lands. Yet in this early era, imperial travelers marked colonized subjects as out of place in both the space of civilization and the space of the nation, and they used that representation of out-of-placeness to define the modernity of Japan, the new territories, and imperial travelers themselves. Tayama Katai summed up this attitude best in a report on his travels through Manchuria and Korea in 1924 (sponsored by the South Manchuria Railway Company). He juxtaposed the new, modern, and Japanified Korea against what he saw as the out-of-placeness of Koreans. Koreans watched as time passed by-Korea the place moved forward while Korea the people stood still. Because of this, they were a "dying nation" (bōkoku suru). ${ }^{88}$ Surveying the scene around him, Tayama commented to his companion, "For the people of Korea, Japan being in charge must be a very difficult thing, don't you think?" "Yeah," Mr. M responded, "that must be true. After all, it seems like there are a lot of people thinking about the past." Tayama described the people of Korea as the "ordinary people of Korea" (Chōsen no jinmin), a term that connoted a people who had not yet recognized their own subjectivity, in contrast to "national people" (kokumin), who embraced their national identity, or even imperial subjects (shinmin), who understood themselves to be a people in relation to the emperor. This designation likewise suggested a temporal difference between the development of Koreans and of the Japanese national people. "But surely they will gradually realize that they are mistaken, right? A good thing is a good thing, no matter what you say," Mr. M continued. Tayama sighed and shook his head. "Customs have strong roots," he explained. He looked out the window of the train. There, among the villages scattered about the low hills, "a Korean wearing dirty white clothes lazily stopped his plow and watched the train passing by." ${ }^{\text {89 }}$

\section{CONCLUSION}

The many modes through which colonial boosters demonstrated the successful incorporation of colonized land into the space of the nation and the space of civilization - and their concomitant displacement of colonized subjects from the 
temporality of their own lands-illuminates how spatial politics emerged through the malleability of place. In this transitional moment between a world of empires and a world of territorial nation-states, it was not enough to simply disappear colonized subjects under a blanket of civilization or to deny their coevalness. Rather, colonial boosters recognized the significance of placing the Japanese nation on colonized land as well. Doing so required the deployment of multiple strategies, which, taken together, kept colonized lands "new" but also made a clear case for their legitimate place within the space of the nation.

The Governments General and the South Manchuria Railway Company deployed similar strategies for representing colonized territory as already integrated into or in the process of becoming part of a Japanese national space. These modes spatialized the relationship between metropolitan and colonial territory-as a synchronic economic relationship of circulation and exchange; as an allochronic relationship of progressive transition to the metropolitan present; and as an affective relationship of national people to the places of national history. The fact that these spatializations overlapped in contradictory ways-Korea and Taiwan were, for example, both becoming Japan and already part of Japanese history and the nationalist land of patriotic sentiment-did not dampen their potential as ways that imperial travelers cum national subjects could understand their own place in a Japan that included the empire. Rather, these overlapping modes offered a shifting sand of relationships that kept the place of colonized territory perpetually in question and thus served as a productive site for imperial travelers' continual reaffirmation of the legitimacy and desirability of colonial rule.

In parsing the place of the colonies through these modes, travelers and colonial boosters operated within a geography of civilization. On the one hand, they saw the space of the nation in terms of an expanding sphere of civilization centered on the inner territory. On the other hand, the territoriality of the geography of civilization was ambiguous. It defined the space of Japan as a liminal location between the universal space of civilization in colonial modernity and the particular civilization of the Japanese nation-state. Likewise, the economic mode and its representation of Japan's circulating mission in Korea, Manchuria, and Taiwan emphasized the liberatory nature of new circulatory technologies, but largely in the frame of a universal discourse of civilization. It was through history, which we discussed in this chapter and will return to in chapter 4 , and language, which we will discuss in chapter 5 , that colonial boosters and imperial travelers made the case that colonized lands were being incorporated into a specifically Japanese national space. This case rested on the notion that the culmination of the historical process of national expansion and integration would result in the disappearance of visible manifestations of cultural difference in Taiwan and Korea. In the South Manchuria Railway Zone, the case was less clear, though ultimately these representations too emphasized the idea that China, the Chinese people, and the ruins of Manchu 
history in Manchuria were residues of a dead past. In contrast, the neatly and generically "modern" architecture of Japanese-controlled cities signified the future that was to come.90

In their insistence on the significance of the changes in the land that the colonial governments had wrought, colonial boosters adopted the modernist notion that the assimilation or modernization of the people would follow that of the land. In the inner territory, the late nineteenth and early twentieth century would see numerous attempts to resolve the so-called social problem of industrial capitalism-persistent poverty and, with the rise of the concept of public health, the recognition that the dangers of industrialism's dark side could not be contained within its dark places-with the redesign of the urban habitat. City officials, architects, and transportation companies attempted to produce modern subjects by transforming the urban landscape into a consciously organized space that materialized an imagination of the city as a microcosm of industrial social life: open spaces, pathways that emphasized the flow and circulation of commodities over congregation, and distinct divisions of space into places of work, leisure, and residence. ${ }^{91}$

From one perspective, then, the production of the colonies as places both within and apart was a "spatial resolution" (kükanteki ketsugi) to political economic contradictions born of global capitalism. ${ }^{92}$ Capital accumulation and resource extraction could proceed with fewer hurdles than in the metropole. The well-being of colonized subjects was not of significant concern to the colonial governments in these early years. The Governments General were quite content to let colonized subjects die through flourishing sales of opium (a government monopoly in the Kwantung Leased Territory and Taiwan), exceedingly harsh and poorly remunerated wage labor, forms of punishment declared too barbaric for the metropole, and squalid living conditions for the lower classes that were made worse through inept government management of services such as sanitation..$^{93}$

From another perspective, however, the overlap between colonial boosters' conceptualization of the relationship between people and land and that of urban planners in the metropole suggests that-despite the territorial-administrative differences between Korea, Taiwan, the Kwantung Leased Territory, the South Manchuria Railway Zone, and the inner territory-the spatial imaginary of the nation was for all self-consciously national subjects an act of voluntarism. In other words, the production of the colonies as problem places also required national subjects to adopt a particular spatial imaginary of the nation against which the colonies could be marked as different, "new," or "not yet" Japanese. It was a sense of self defined by a sense of place. It was an act of choosing to connect oneself to a place whose location was defined by global and national networks of circulation and nationalist metageographies and whose essence was likewise defined in the commensurable spatial and temporal terms of nations in a global world. It was 
this act of voluntarism that the colonial policy of assimilation sought to elicit from Taiwanese Chinese and Koreans. And it was likewise an act of voluntarism that colonial boosters and urban planners sought to elicit from metropolitan travelers.

If, in rhetoric, the ability to participate fully in the nation was a matter of voluntarily constituting one's sense of self within a new spatio-social imaginary, in practice, it was a far more complex matter. In the post-World War I era, the demand that citizens and subjects rise out of their local place would collide with a new regime of internal and external borders that disproportionately affected the mobility of colonized subjects. It was in this context of democratization and bordering that the primary axis of spatial politics would shift from a geography of civilization to a geography of cultural pluralism and the mobility of the tourist would become a central ideological mechanism through which colonial boosters produced an imperial spatial and social imaginary for a second generation of imperial subjects. 